\title{
Hungary in the Late Eighteenth Century
}

\section{THE DECLINE OF ENLIGHTENED DESPOTISM}

\author{
BELA K. KIRALY
}

Under the Habsburg rulers Maria Theresa and Joseph II, attempts were made to introduce reforms in Hungary and to bring Hungary more directly under the control of the Austrian court in Vienna. This centralizing trend was brought to an end in 1790 , in a period of crisis, when the privileges of the Hungarian feudal nobility were reasserted. Mr. Kiraly attempts to show that the crisis, though resolved in favor of reaction, nevertheless contained and revealed all of the essential elements of the forces in Hungarian society that were to bring about social changes in the nineteenth and twentieth centuries. T This is a volume in the East Central European Studies of Columbia University. Bela K. Kiraly, now Associate Professor of History at Brooklyn College, was superintendent of the War Academy in Budapest in $1950-51$.

COLUMBIA UNIVERSITY PRESS, 440 West I Ioth Street, New York, N.Y. IO025 Address for orders: 136 South Broadway, Irvington, N.Y. I0533

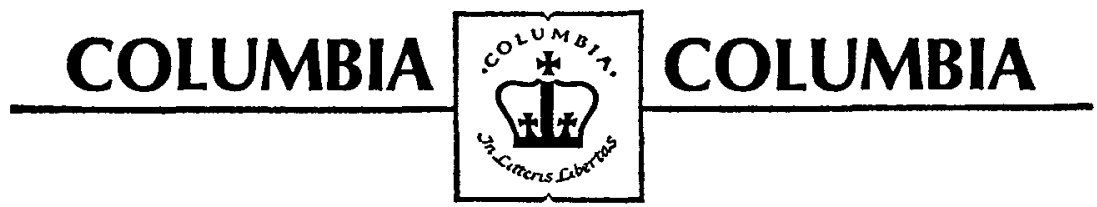

INTRODUCING A NEW QUARTERLY ...

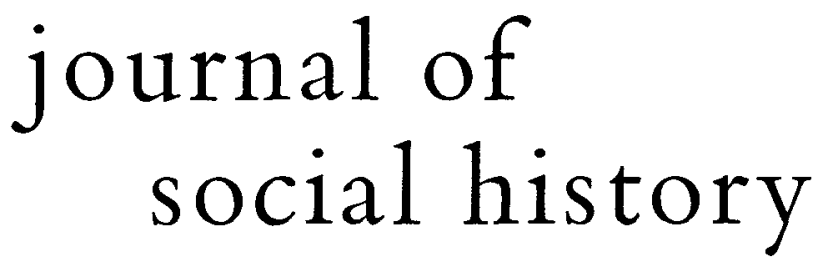

The first English-language journal to concentrate specifically on social history, JSH focuses on the period from 1700 to the present and covers Europe (including Russia) and the United States.

JSH carries articles and book reviews by historians, sociologists, economists, anthropologists, and other scholars from around the globe.

Editor: Peter N. Stearns

96 pages per issue

Order from:

$\$ 10.00$ a year

THE UNIVERSITY OF CALIFORNIA PRESS

Periodicals Dept., Berkeley, California 94720 